\title{
Centenário de nascimento de José Ulpiano Pinto de Sousa.
}

\footnotetext{
Comemorou-se solenemente, nesta Faculdade, o centenário de nascimento de José Ulpiano Pinto de Sousa, que foi emérito professor de Direito Civil.

Reuniu-se a Congregação, no salão nobre, aos 14 de abril de 1970, para reverenciar-lhe a memória, sendo encarregado do panegírico o Prof. Dr. Sílvio Rodrigues, sucessor da cátedra do homenageado, que o fêz nos termos do seguinte discurso.
}

\section{Discurso do Professor Dr. Silvio Rodrigues.}

A Congregação dos Professôres da Faculdade de Direito da Universidade de São Paulo se reune, nesta solenidade a fim de render homenagem à memória de um dos seus grandes vultos. Eu invoco a lembrança do professor emérito José Ulpiano Pinto de Souza, ao ensejo do centenário de seu nascimento.

Esta Casa tira sua fôrça do seu glorioso passado; e, ao projetar-se para o futuro, de certo procura exaltar seus ancestrais, cultuando-lhes as virtudes, pois o paradigma de nossos maiores. sem dúvida, será a fonte inspiradora do presente e do porvir.

Entre essas grandes figuras, que deixaram o sinal de sua passagem por êstes vetustos corredores franciscanos, a de José Ulpiano Pinto de Souza certamente se enfileira, como a de um exemplo a ser seguido.

Homem simples e correto, pessoa de grande sensibilidade, jurista de enorme penetração, escritor preciso, chefe 
de família exemplar, advogado de grande tirocínio, o mestre cujo centenário se comemora honrou a Escola do Largo de S. Francisco, como honrou a ciência jurídica brasileira.

José Ulpiano nasceu aos 18 de setembro de 1869, na cidade de Casa Branca, filho do Sr. Manoel Joaquim Pinto de Souza e de d. Francisca de Aguirre e Souza, gente de fina linhagem e de boa tradição cultural. Seus pais, quando ainda criança o futuro mestre, mudaram-se para Rio Claro, onde o nosso homenageado passou a meninice. Completados os primeiros estudos, foi enviado para o Colégio de Itu, dirigido por jesuítas, instituto de alta reputação àquela época e para onde iam os filhos de gente abastada de todo o interior de São Paulo e mesmo da Capital.

Nesse colégio completou os seus estudos ginasiais. Foi sempre aluno aplicado, distinguindo-se entre seus colegas, graças à sua notável memória e grande inteligência, ambas reveladas desde os verdes anos.

Terminado o curso secundário, veio para São Paulo, indo morar na rua Aurora, em casa de parentes. Transcorria o ano de 1887, e José Ulpiano, no esplendor de seus 18 anos, matriculou-se na Academia. Dedicou-se, com afinco, aos estudos, durante o curso, distinguindo-se entre seus colegas de turma, entre os quais figuravam homens que mais tarde iriam se tornar ilustres na política, no magistério público, nas letras. Dentre todos tornou-se amigo de dois dêles, que eram seus companheiros de estudo: Washington Luiz Pereira de Souza e Pedro Moacyr. Realmente, ligou-os grande amizade.

Pedro Moacyr, natural do Rio Grande do Sul, homem que veio a ser um dos maiores tribunos de seu tempo, quando deputado federal e residente no Rio de Janeiro, demandava São Paulo freqüentemente, para visitar seu amigo José Ulpiano e pedir-lhe conselhos, conselhos êsses sempre inteligentes e originais. 
Homem fechado, de pouca exteriorização, José Ulpiano só podia sentir com grande profundidade e esta só a poucos pode abarcar. Foi um dos traços de sua personalidade: não se derramou a muitos, superficialmente. mas concentrou-se a um círculo restrito. Só êsses poucos o conheceram em sua grandeza, dai a amizade que lhe devotaram, pois sabiam que a de José Ulpiano, em relação a êles, tinha raízes na alma, pairando muito acima das vicissitudes cotidianas.

Realmente, José Ulpiano era o amigo que mais se mostrava nas ocasiões de dar, ou seja nas horas de tristeza, do que nas de receber, isto é, nas festividades. Prova-o sua atitude em face do seu amigo de tôda vida, o grande Frederico Steidel, também mestre insígne desta casa.

A amizade que os ligava era enorme; aliás por longos anos, foram companheiros de escritório. Quando moços ambos, era o pai de Steidel homem abastado, que apreciava entreter a sociedade, que recebia muito e cuja casa vivia cheia de amigos e aduladores. Ulpiano, sempre arredio, tímido, não freqüentava a mansão dos Steidel, a despeito dos convites insistentes do anfitrião e do filho, seu amigo e colega.

Porém, quando o infortúnio atingiu a casa alegre dos Steidel $\mathrm{e}$ as ruidosas companhias dela se afastaram, o primeiro a bater à porta daquela residência, para de lá nâo arredar, enquanto não se refez o conceito e a fortuna da família, foi José Ulpiano. Frederico Steidel jamais esqueceu a dedicação, e a profundidade do sentimento daquêle amigo, cuja aparência fria dava a impressão de indicar o contrário.

Contaram-me familiares do homenageado que Steidel nada fazia sem consultar o amigo; José Ulpiano era o seu conselheiro. Tôdas as decisões referentes a êle e a sua família tinham que ter o "referendum" de José Ulpiano. Aliás, não era apenas Steidel a tê-lo como conselheiro. 
Homem ponderado e refletido, a quem a cultura se formara não apenas na leitura, mas, sobretudo, na arguta observação dos fatos, José Ulpiano converteu-se em conselheiro de amigos, políticos e homens de negócio. Seu escritório, onde êle e o companheiro Steidel, tinham tanto sucesso, situado à Rua São Bento, e no qual o mestre trabalhou por mais de quarenta anos, viu transpor os seus umbrais tôdas as personalidades da época. Iam ouvir José Ulpiano. Homem de grande experiência, a serviço de uma madura reflexão, tinha-se a ganhar escutando suas ponderações. Sabiam-no desprendido, disposto a dar sem nada pedir de volta. Porém, se distribuía conselhos e pareceres, não entregava a todos seus sentimentos. Estes, como disse. reservava para um pequeno número de amigos diletos.

Dessa forma, não se limitou em ser o jurisconsulto, a quem se consultava sôbre controvertidas questões de direifo; não se restringiu em ser o advogado combativo, a quem se entregavam as causas difíceis, ou em ser o professor a quem os discípulos admiravam vendo-o explicar intrincados princípios do direito romano ou do direito civil. Foi além: converteu-se em humanista, de profunda compreensão das coisas da vida social, política, econômica, educacional e familiar. E era no imenso cabedal de sua visão humanística que os consulentes iam buscar a orientação a seguir, o esclarecimento desejado, a lição necessária, o apoio requerido ou a confirmação do que supunham fôsse o certo.

Em 1891, José Ulpiano conclui o curso universitário. João Mendes Júnior, amigo de seu pai, recebe o recém formado em seu escritório. Dêsse preclaro mestre colheu nosso homenageado dois ensinamentos, que o acompanharam por tôda sua longa existência: primeiro, o amor à pesquisa jurídica e à cátedra, como forma de transmitir o produto do seu labor aos jovens; segundo, o apêgo à monarquia como sistema de organização política. Ambas 
as lições ficaram gravadas no seu sêr, e disso deu provas: ao ser indicado para exercer a interventoria em São Paulo. em começos de 1932, ao lhe ser formulado o convite, disse ao mensageiro de Getúlio Vargas, general Miguel Costa. E parece serem textuais as palavras: "vivi para minha família, para a minha cátedra e para as minhas convicções políticas; estou por demais idoso para mudar de rumo. Obrigado, mas não aceito."

Sofreu, aliás, as conseqüências de suas convicções politicas. Ao paraninfar a sua primeira turma, ainda como professor substituto, teceu, em seu discurso, encômios à monarquia e endereçou críticas à jovem República. Rodrigues Alves, Presidente do Estado, que se achava presente à solenidade, nunca mais perdoou o jovem professor $\mathrm{e}$ recebeu como afronta a palavra de José Ulpiano, ousando criticar a nova forma de govêrno, que êle, Presidente do Estado, presente ao ato, servia com convicção.

Quanto à outra lição de João Mendes Júnior, José Ulpiano tudo fêz para realizá-la: cinco anos após a sua formatura, em 1896, contando apenas 26 anos de idade, inscreveu-se e foi aprovado em concurso para lente substituto desta Faculdade. À época, os ilustres professôres desta casa, como está voltando a ocorrer agora, para bem dêste país, eram sempre chamados para a vida política ou para exercer cargos de alta administração pública, cargos em que são traçados os destinos desta nação. Assim José Ulpiano, professor substituto na ocasião, esteve sempre ocupando a cátedra no lugar dos mestres convocados para a vida pública. Lecionou quase tôdas as disciplinas do currículo. Em 1908 tornou-se professor catedrático de Direito Civil, matéria em que se especializou e se notabilizou.

A sua formação humanista levou-o a exercer a cátedra em nivel muito alto, pois não se limitava aos aspectos de técnica jurídica no expor a matéria. Ia além, enfeixava-a numa visão filosófica e sociológica do fenômeno jurídico. 
Descia às entranhas da problemática jurídica, para dela extrair o princípio norteador da questão de direito em causa.

Vicente Ráo, em formosa conferência proferida perante a Congregação dos Professôres desta Academia, por ocasião do trigésimo dia do falecimento do nosso homenageado, e realizada a 30 de abril de 1957 , observou quão espinhosa era a seára do civilista, no período imediatamente anterior à promulgação do Código Civil de 1916.

A legislação era confusa e a doutrina um mar de controvérsia. Se a fonte primordial do Direito Civil pátrio eram as ordenações Filipinas, a complementá-las, ou a modificá-las, havia um número enorme de regras extravagantes, decorrentes de leis supervenientes, alvarás, cartas régias, assentos da Casa de Suplicação, etc., isso além das Glosas de Bártolo e de Acursio, as opiniões dos jurisconsultos, as leis das demais nações, se conformes com a "boa razão"; a despeito da Consolidação das Leis Civis, de Teixeira de Freitas e da Recopilação de Carlos de Carvalho, o oceano em que navegava o civilista era proceloso e o problema de saber, realmente, qual o texto legislativo em vigor, apresentava-se relevante para o jurisperito.

A formação cultural profunda de José Ulpiano, como observou Vicente Ráo, o punha acima da procela. Pois, seu conhecimento dos princípios, suas investigações próprias, abriam-lhe um caminho que em geral se encontrava fechado para outros estudiosos mais superficiais.

Arnaldo Vieira de Carvalho, cujo consultório se localizava no mesmo edifício da rua de São Bento onde José Ulpiano e Steidel tinham escritório, nunca entrava ou saía de seu trabalho sem dar um dedo de prosa com José Ulpiano, para ouvi-lo comentar os últimos acontecimentos ou discorrer sôbre os problemas do pais. Ligou-os, igualmente enorme e mútuo afeto o que freqüentemente ocorre entre homens da mesma grandeza espiritual. 
Já idoso, tendo perdido seus dois amigos mais chegados, isto é, João Arruda e Frederico Steidel, havendo a morte lhe roubado, igualmente, outros companheiros que também lhe eram caros, José Ulpiano isolou-se, para conviver apenas com a família. Ai exerceu mais uma vez o seu nobre magistério. Com os filhos já criados, freqüentando cursos superiores, José Ulpiano, às noites, sentava-se na velha cadeira de balanço e em seu redor distribuía-se a família. Iniciava-se o diálogo entre pai e filhos. Diálogo que continha sempre uma lição de bom senso a respeito dos problemas gerais da vida. Contou-me um dêles, meu querido colega Roberto Pinto de Souza, que José Ulpiano tinha o dom, junto aos filhos, de não pontificar, mas de ponderar. De fazê-los, pelo raciocínio sôbre os fatos qüotidianos, compreender a essência dos mesmos e o que dêles se poderia extrair como conhecimento da realidade e, ao mesmo tempo, como norma de comportamento. De tal forma conduzia o diálogo, que filho nenhum lhe pedia autorização para fazer isso ou aquilo, mas solicitava a opinião do pai, que discorria como conselheiro, apontando as vantagens e desvantagens de uma determinada linha de conduta; e ao chegar à conclusão, esta valia como esclarecimento e não como imposição. O filho que tomasse a decisão, face às considerações que fizera o pai.

A austeridade de José Ulpiano refletia-se não só em sua aparência, como, sobretudo, em suas atividades. Se com os outros mostrava-se tolerante, era austero consigo mesmo. Para si próprio impunha disciplina rígida e seus hábitos eram morigerados. Dava a impressão de um espartano. Recolhia-se cêdo e mal o sol nascia, já o encontrava de pé. Alimenta-se frugalmente e suas distrações eram tôdas de caráter cultural. A austeridade que o cercava não surgia como algo que the havia sido imposto; ao contrário, decorria da própria natureza de sua personalidade. Era alguma coisa que corria com seu sangue. 
Daí refletir-se em tudo que fazia. Porém. tal austeridade não vinha acompanhada de orgulho ou intolerância; não tirou do mestre a marca de humanista que constituía o traço dominante de sua pessoa. Isso explica o trato. Ihano e amável, que dava a todos, sem distinção de fortuna ou posição.

É que devotava imenso respeito ao ser humano. Não tomava os indivíduos por suas representações sociais nem os distinguia por sua fortuna; mas via em cada qual uma pessoa humana, merecedora de tôda consideração e de tôda cortesia. Por êsse motivo jamais desconsiderou a alguém. Quando se dirigia a alguma pessoa, fôsse ela cliente abastado ou jardineiro de sua casa, chamava-a de "senhor". $\mathrm{E}$; se na rua, cumprimentava alguém - o amigo chegado ou a empregada doméstica - tirava sempre o chapéu.

José Ulpiano que tão brilhantemente exercia o magistério desfrutando de grande conceito junto aos alunos desta casa, aposentou-se relativamente cedo. Fê-lo porque sentiu que os muitos anos de magistério ininterrupto já começavam a cansá-lo. Destarte, acreditou não poder mais dispensar aos discípulos o cuidado que sempre lhes devotara. Receava, no recôndito de sua consciência escrupulosa, que se a qualidade de suas aulas decaísse por falta sua, advinda dos longos anos de ensino, estaria traindo a mocidade. Portanto, decidiu afastar-se, antes que isso ocorresse, para que outro mestre, portador do entusiasmo da juventude, o substituísse e levasse avante a tarefa sublime de orientar a mocidade. Em 1926 deixou esta casa, que novamente o recebeu, em 1951, para lhe conferir o tífulo de Professor Emérito.

Prevaleceram mais uma vez a ponderação e o bom senso, pedras de toque de sua personalidade.

Espiritualista que era, José Ulpiano acreditava na idéia como elemento primeiro. Achar a idéia em si mesma, na sua acepção pura, consistia a meta do pensador. Em 
sua formulação abstrata, contudo, a idéia, se bem tivesse valor e fôrça, carecia de aplicação como tal. Haveria necessidade de transferi-la para o real, de qualificá-la, de forma a poder ajustar-se às contingências da vida universal. No terreno do Direito, as idéias de propriedade, de família, de pessoa, enquanto encrustadas em suas formulações abstratas eram de pouca aplicabilidade; entretanto transpostas para a sociedade e consideradas em face do emaranhado das contingências sociais do momento, adquiriam majestade. A seu ver a função do professor residia nisso: dar aos jovens a possibilidade de raciocinar sôbre a idéia em sua formulação pura, ensejando-lhes o meio de transpô-la para a norma e, desta, para o caso concreto.

O objetivo de José Ulpiano, como professor, era o de dar consciência do direito, em sua formulação abstrata, ao estudante, conferindo-lhe, ao mesmo tempo, os elementos necessários para aplicar as regras jurídicas à sociedade contemporânea.

A idéia permanece - a sociedade, em sua evolução, transforma-se.

Meditador acurado, atraía para seu convívio aquêles para os quais a meditação era exercício qüotidiano. Assim, João Arruda, insígne mestre desta Casa, sentiu-se atraido por José Ulpiano e tomou-o como seu companheiro de todos os dias, para o entretenimento nobre dos debates abstratos. Tôdas as noites, durante anos seguidos, mal terminava o jantar, João Arruda dirigia-se para a casa de José Ulpiano e lá ficava horas a fio a entreter-se com o amigo, discutindo assuntos transcendentais. Nasceu entre ambos sólida amizade. Envelheceram juntos e só a morte os separou.

Era intuito de José Ulpiano afastar-se de quaisquer encargos de caráter intelectual. Todavia o movimento de constitucionalização do país, cujo ponto mais alto refletiuse na Revolução de 1932, o chamou novamente à liça. 
Vencida a gente paulista naquela memorável Revolução, não obstante deu frutos o glorioso movimento. Logo após o govêrno central convocou a Assembléia Constituinte. O Estado derrotado, ainda unido, levantou de nôvo, desta vez pacificamente, a bandeira das treze listas, almejando conduzir ao parlamento constitucionalista, a elite intelectual da terra. E, novamente, os organizadores da "Chapa Única por São Paulo Unido" vieram buscar nesta casa os grandes nomes que a iriam compor.

Nela figuravam as figuras venerandas de Jorge Americano, de José Cardoso de Mello Netto, de Waldemar Ferreira, de Alcântara Machado e de José Ulpiano Pinto de Souza.

Só a insistência dos amigos, companheiros e admiradores, quebrou a resistência de nosso homenageado. Eleito deputado com grande votação José Ulpiano ruma para o Rio de Janeiro e é deputado dos de maior ponderação e equilíbrio. Sua coerência continua manifesta e se reflete, ainda uma vez, na recusa em dar seu voto a Getúlio Vargas, quando é êste candidato à presidência da República.

Aliás outro episódio vem realçar sua posição de fidelidade aos princípios orientadores de sua formação. Promulgada a Constituição de 16 de julho de 1934 e dissolvida a Assembléia Constituinte, fundou-se em São Paulo o Partido Constitucionalista. Um dos chefes do novo partido, o ilustre Alcântara Machado, foi à casa de José Ulpiano a fim de convidá-lo para inscrever-se na agremiação e candidatar-se à reeleição.

"Alcântara - respondeu-lhe José Ulpiano - nunca servi a República, não é agora que vou fazê-lo. Aceitei, por imposição do momento, participar da Assembléia Constituinte, porque entendi ser uma honra que me concediam os meus concidadãos e uma oportunidade de servir minha pátria. Pleitear agora cargo eletivo e inscrever-me em um 
Partido, considero servir ao que as minhas convicções não me permitiram que o fizesse."

José Ulpiano, com a modéstia que a austeridade e o bom senso lhe davam, nunca permitiu que se lhe tributassem homenagens. Sempre que seus admiradores se animavam a promover festividades em sua honra, a principio e veladamente procurava dissuadir que o fizessem. Se não o conseguisse, amàvelmente agradecia a intenção $\mathrm{e}$ pedia encarecidamente que a não promovessem.

Em março de 1957, depois de prolongada enfermidade, faleceu José Ulpiano. Esta Faculdade rendeu-lhe homenagem, ao descer ao túmulo, pela palavra do preclaro professor Waldemar Ferreira e reverenciou-lhe a memória, em sessão solene, pelo belíssimo estudo que dêle fêz o eminente professor Vicente Ráo, ambos antigos alunos de José Ulpiano.

Agora, por ocasião do centenário de seu nascimento, a Congregação dos professôres da Faculdade de Direito da Universidade de São Paulo, pelo seu apagado intérprete, rende ainda uma nova homenagem ao seu grande mestre José Ulpiano Pinto de Souza. 